\title{
PRODUCTION OF L.E. CELLS IN VIVO BY TRANSFUSION OF SYSTEMIC LUPUS ERYTHEMATOSUS PLASMA
}

\author{
BY \\ GEORGE BENCZE, STEVEN CSERHATI, JOSEPH KOVACS, AND \\ TIBERIUS TIBOLDI
}

From the First Department of Medicine, University Medical School, Szeged, Hungary (Director: Prof. G. Hetenyi)

The plasma of patients suffering from systemic lupus erythematosus (S.L.E.) contains a factor which leads to L.E.-cell formation if normal bone-marrow or white blood cells are tested with this plasma in vitro (Haserick, Lewis, and Bortz, 1950).

This L.E. factor can be found not only in plasma, but in various other body fluids, such as the cerebrospinal, pleural, and pericardial fluid (Bencze, 1956), in urine, and in cantharides pustules. This L.E. factor passes the placenta barrier, and Bridge and Foley (1954) have observed L.E. cells in the peripheral blood of a baby whose mother suffered from S.L.E.

Hitherto, the successful transmission of the plasma factor and the production of L.E. cells in normal persons in vivo has not been reported, nor have any such experiments been successful in animals. The present paper reports the production of the L.E.-cell phenomenon in patients without collagen disease after the transfusion of S.L.E. plasma.

\section{Method}

Plasma was obtained from a patient suffering from S.L.E. (of blood group AB), in whose peripheral blood L.E. cells had repeatedly been observed (Fig. 1). The blood was taken under sterile conditions, using $16 \mathrm{ml}$. citrate to $100 \mathrm{ml}$. blood, kept for $24 \mathrm{hrs}$ at $-4^{\circ} \mathrm{C}$., and centrifuged. The blood thus obtained was always L.E.-cell positive, as demonstrated by the rotatory method of Zinkham and Conley (1956) and the ring method of Snapper and Nathan (1955).

\section{Experiments}

(1) A man aged 24 (blood group B), in whom the diagnosis of Hodgkin's disease had been verified histologically, received $200 \mathrm{ml}$. of this S.L.E. plasma. The transfusion was uneventful. L.E. cells had never previously been found in his blood,

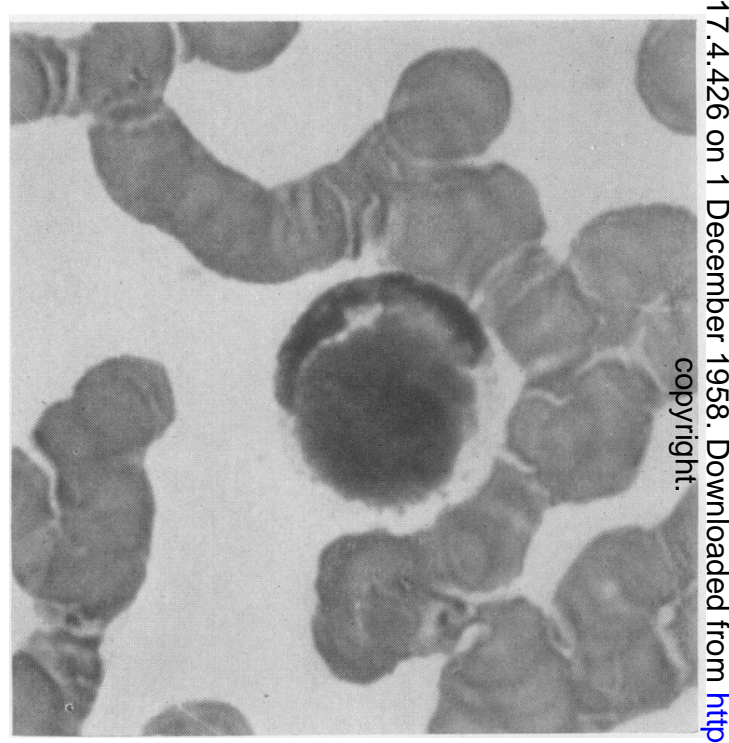

Fig. 1.-L.E. cell of a patient with systemic lupus erythematosus.

but 2 hours after the transfusion the peripheral $\frac{0}{3}$ blood contained many L.E. cells, which reached their maximum 6 to 24 hours later. 11 days aftero the transfusion, L.E. cells could only be observed occasionally, but they could still be recognized even 음 27 days later (Figs 2 and 3, opposite). As a control, 35 days later, the same patient was given $400 \mathrm{ml}$. normal plasma (blood group AB), obtained in exactly the same way as the S.L.E. plasma. The transfusion was uneventful. L.E. cells were searched for 0 30 minutes, 2, 4, 6, 24, and 48 hours after the N transfusion, but without success.

(2) A man aged 72 (blood group O), with ao diagnosis of carcinoma of the prostate with metastases, received $200 \mathrm{ml}$. S.L.E. plasma. L.E. cells $\stackrel{?}{+}$ had not previously been found in this patient's blood, 


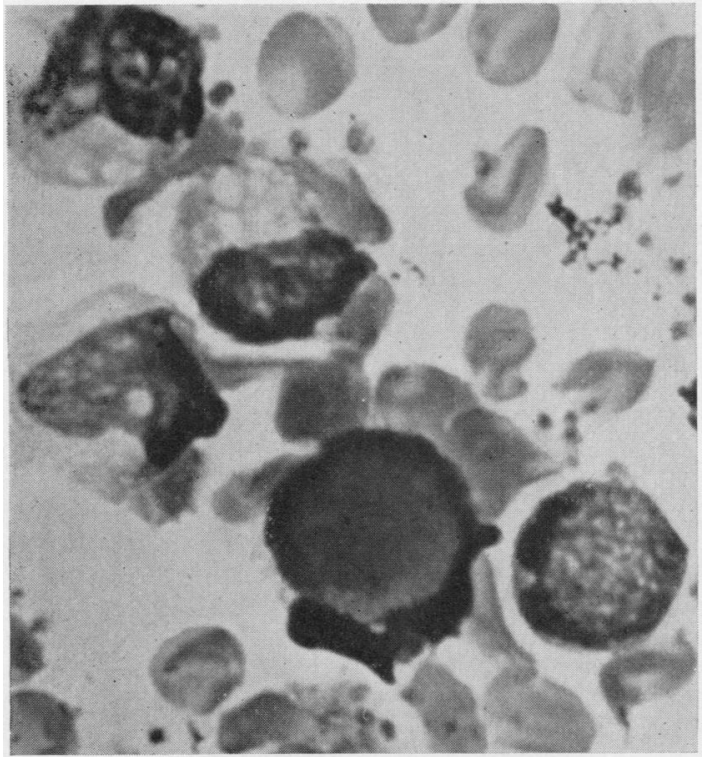

Fig. 2.-L.E. cells in peripheral blood of receptor 24 hours after transfusion.

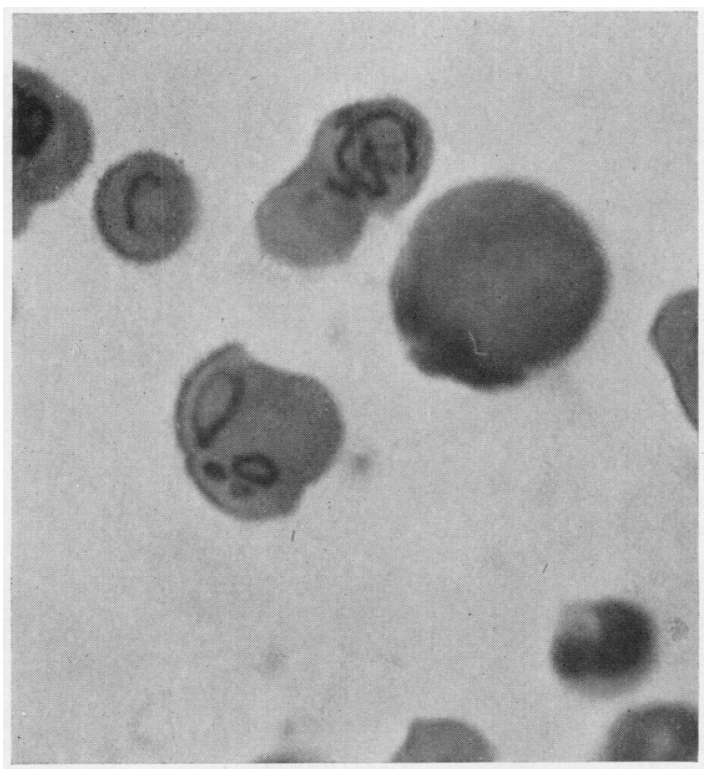

Fig. 3.-L.E. cells in peripheral blood of receptor 27 days after transfusion.

but 2 hours after the transfusion the peripheral blood contained a large number of L.E. cells, which reached their maximum 6 to 24 hours later (Fig. 4). After 24 hours their number slowly decreased; some could still be found on the tenth day, but from the eleventh day only occasional L.E. cells were observed.

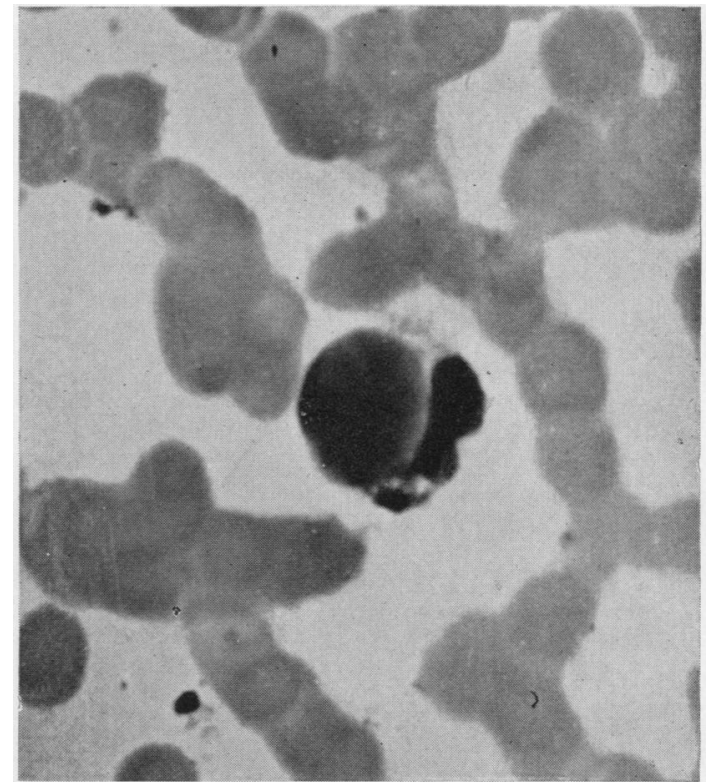

Fig. 4.-L.E. cells in peripheral blood of receptor 24 hours after transfusion.

(3) A woman aged 52 (blood group A), with a diagnosis of carcinoma of the ovary with metastases, received $140 \mathrm{ml}$. S.L.E. plasma. No L.E. cells had previously been observed in her blood. After the transfusion she developed a chill and her temperature rose to $39^{\circ} \mathrm{C}$., but she soon recovered without other complications. Her peripheral blood contained a striking number of L.E. cells and 10 days later they were still numerous.

\section{Discussion}

The L.E.-cell phenomenon has been produced in the blood of three patients suffering from conditions other than collagen disease by transfusing plasma from a patient with S.L.E. In all three, many typical L.E. cells could be observed as early as 2 hours after the transfusion, and for 10 days afterwards, the maximum being seen from 6 to 24 hours after the transfusion. The number of induced L.E. cells surpassed that in the blood of the donor patient. In one case, 60 to 80 L.E. cells per 1,000 leucocytes were present as compared with 30 to 40 per 1,000 granulocytes in a smear from the donor. From the eleventh day L.E. cells were found only occasionally, but in the first case a few could still be observed after 27 days.

These experiments prove that plasma from S.L.E. patients contains a factor which is responsible for the formation of L.E. cells, and which enables the L.E.-cell phenomenon to be reproduced in other 
subjects. Up to now the existence of the L.E. factor in plasma has been demonstrated only in vitro by treating normal bone marrow or white blood cells with S.L.E. plasma. The present experiments have proved the transmission of L.E. factor by producing L.E. cells in persons without S.L.E.

Future experiments will aim at discovering whether the plasma factor can be held responsible for any changes occurring in S.L.E.

\section{Summary}

$200 \mathrm{ml}$. plasma from an L.E.-cell positive woman was administered to three patients with malignant disease, in whom L.E. cells formed almost at once, with a maximum between the 6th and 24th hours.

\section{REFERENCES}

Bencze, G. (1956). Mag. belorv. Arch., 2, 33.

Bridge, R. G., and Foley, F. E. (1954), Amer. J. med. Sci., 227, 1-9.
Haserick, J. R., Lewis, L. A., and Bortz, D. W. (1950). Ibid., 219, 660.

Snapper, I., and Nathan, D. J. (1955). Blood, 10, 718.

Zinkham, W. H., and Conley, C. L. (1956). Bull. Johns Hopk. Hosp., 98, 102.

Production des cellules L.E. in vivo par transfusion du plasma affecté par lupus érythemateux généralisé

\section{RÉSUMÉ}

On administra à trois femmes atteintes d'une maladie maligne 266 c.c. de plasma provenant d'une femme chez qui on avait démontré la présence de cellules L.E. Les transfusés formèrent des cellules L.E. presque immédiatement, avec un maximum entre la 6ème et la 24ème heure.

Producción de células L.E. in vivo por transfusión de un plasma con lupus eritematoso generalizado

\section{Sumario}

Se administraron a tres mujeres afectas de una enfermedad maligna 266 c.c. de plasma procediendo de una mujet con células L.E. comprobadas. Las recibidoras $\vec{V}$ formaron células L.E. casi inmediatamente, con un is máximo entre las 6 y las 24 horas. 